\title{
Ethical disputes
}

\author{
Francesco Agnoli • Lodovico Balducci • \\ Giancarlo Cesana
}

Received: 3 January 2012 / Accepted: 3 February 2012/Published online: 2 March 2012

(C) Springer-Verlag 2012

On October 13, 2011, Giuseppe Remuzzi authored an article in Lancet [1] where he makes unsubstantiated historical claims.

The death of the Italian Prime Minister, Cavour, in 1861 might have been due to overuse of therapeutic phlebotomies. Based on this event, Remuzzi asks why Italy had lost her leadership position in medicine and other scientific fields by the 1800s. The question itself is scarcely justified. At that time, phlebotomies were considered legitimate for treatment of multiple diseases. An icon of American medicine, Dr. Benjamin Rush, is now accused of having killed more patients with phlebotomies in trying to cure an epidemic of yellow fever in Chicago than the yellow fever ever did. Cavour's physicians were practicing medicine according to the best, accepted current standards.

Remuzzi blames the influence of the Catholic Church for the decadence of Italian medicine. To this end, he quotes an old article published in Lancet that tried to establish a nexus between the crisis in Italian science and the expulsion of 15 scientists, guilty of heresy, from papal Rome after 1861. "The Rome that expelled these scientists is the same Rome that has persecuted Galileo" stated an editorial of the Boston Medical and Surgical Journal.

Here one cannot help noticing a serious contradiction in Remuzzi's argumentation. As Remuzzi himself recognizes,

\author{
F. Agnoli \\ Historian and Journalist, Il Foglio, Rome, Italy \\ L. Balducci \\ Moffitt Cancer Center Tampa, Florida, USA \\ G. Cesana $(\bowtie)$ \\ Research Centre on Public Health, University of Milano \\ Bicocca, Monza, Italy \\ e-mail: giancarlo.cesana@unimib.it
}

Italy has been the "Nursery of natural sciences" and the debts of other countries, including Great Britain, to Italian science, is so high that it cannot even be estimated. It should be also recognized that Italy's leadership role in sciences over the centuries had been obtained thanks to the Catholic Church. Thanks to the anthropocentrism promoted by the Book of Genesis and the belief in a rational God (logos) implicated in the Christian faith, a rational exploration of the world was made possible. Without Christianity, European people may still cultivate superstition and magic instead of science [2-4].

During the barbaric invasions that ravaged what had been the Roman Empire, the Benedictine monks, and the monks of Cassiodorus endeavored to save the scientific discoveries of the classic age that otherwise would have been permanently lost.

Furthermore, the first university was established in Bologna one of the capitals of the Papal States. The first school of natural sciences developed at the University of Oxford and included among its teachers prominent members of the Catholic clergy, such as Roberto Grossatesta and Ruggero Bacone that opened the way to the experimental method. In general, during the middle age, the Pope had been the most vocal and influential promoter of sciences and scientific education.

Modern science was born in the Italian university with the support and encouragement of the Church. The first anatomic dissections were performed in Bologna, with Mondino de Liuzzi and in Padua, where the Flemish Vesalius started drawing his world famous anatomic cartoons. It is universally recognized that the Church enabled and sponsored anatomical studies despite the objections of physicians of the Galenian tradition, of some humanists and of the populace.

The historian Giovanna Ferrari, referring the work of RK French and A. Cunningham wrote: "The clergy 
promoted the exploration of the human body, as a unique opportunity to admire and glorify the work of the Creator and to strengthen the authority of the Church, by revealing the correspondence of Christian principles and natural laws". This finding, supported by most scholars, overturns the myth of an obscurantist church, enemy of the scientific progress. To the contrary, the support of the church explains the development of anatomical sciences in Christian Europe before anywhere else in the world [5-7].

Further, everybody agrees that medical sciences were boosted by the development of hospitals. The first Western hospital was funded by a Catholic woman named Fabiola in the fourth century, in Rome. Furthermore, for centuries, the Christian monks were both pharmacists and physicians, offering assistance to the poor and the sick in their hospices/hospitals. Thanks to the monks of Montecassino the first Schola medica of Europe was born in Salerno.

The hospital as an institution stems from Christianity. Over the centuries, hospitals and centers of isolation for leprosy or for epidemics were funded uniquely by religious orders and confraternities. The charity inspired by the love of the neighbors gave births to the institutions, the hospitals, where medical education, training and research eventually took place.

Let us not forget some prominent scientists who found their inspiration in the Christian faith. Nicolo Copernico was a devout canonic and possibly even an ordained minister. The father of crystallography, Nicolo Stenone, became Christian thanks to the influence of Galilei's disciples and eventually was ordained priest and bishop. The father of modern genetics was Gregory Mandel, a monk; the discoverer of the first genetic disease was Jerome Lejeune, a Servant of God; Father Benedetto Castelli, perhaps the closest friend of Galileo, developed the modern hydraulic concepts, and the first person to hypothesize the "big bang" was the Jesuit Father George Lemaitre.

When confronted with this historical background, the accusation of Remuzzi that the Catholic Church was the cause of the decline of Italian science appears totally unfounded. The expulsion of the 15 "so called" scientists from papal Rome in 1861 appears as an anecdote totally irrelevant to the greater issue. One may also question as to why the decline of Italian science continued when the Italian government was completely free of any religious influence between 1870 and 1929, and the Pope had become just a prisoner in the Vatican? Why did the 15 scientists expelled from Rome fail to enlighten the rest of the peninsula with their wisdom?

However, the conclusion of Remuzzi's article is most disconcerting. He claims that the negative influence of the Catholic Church on Italian science persists today and he brings as example the fact that the Catholic Church opposes "in vitro" fertilization (IVF) and the use of human embryonic stem cells for research. In addition, Remuzzi accuses the Catholic Church of obscurantism when it opposes the practice of euthanasia.

One has to ask Remuzzi how can the legalization of euthanasia promote any type of scientific advance? Should the readers of Lancet believe that the medical research in other countries is more advanced because euthanasia is allowed? This claim would be denied by the facts themselves. Euthanasia is illegal in the USA and yet the primacy of the American science is universally acknowledged.

The idea that the procedures involved in IVF (sperm and oocyte banking) represent scientific advances implies that science is neutral with respect to humanity and that in the name of science one might manipulate and eventually destroy humanity. This claim is tantamount to allowing physicists to use the atomic bombs just because they had discovered it!

When speaking of research on embryonic stem cells, Remuzzi forgets that from a pure scientific viewpoint, an embryo is a human life. The phenomenon we call life is the ongoing decompression of a unique file contained in the DNA of each individual and this process begins at the moment of fertilization. Any other definition of human life is arbitrary and self-serving and would justify the destruction of some human beings for the benefit of others. These implications do not seem to bother Remuzzi but fortunately are of concern to the European Court [8]!

\section{References}

1. Remuzzi G (2011) Ethical disputes still beset Italian medicine 150 years after Count Cavour's death http://www.thelancet.com Published online 13 October 2011 doi:10.1016/S0140-6736(11) 61382-2

2. Sironi V (2006) Ospedali e medicamenti. Bari, Laterza

3. Mollat M (2001) I poveri nel Medioevo. Bari, Laterza

4. Scarano GB (1993) La scuola medica salernitana. In: AA.VV Elementi di storia della medicina, Padova, Piccin, p 132

5. Ferrari G (2008) Tra medicina e chirurgia: la rinascita dell'anatomia e la dissezione come spettacolo. In: Il Rinascimento Italiano e l'Europa: le scienze, vol V. Vicenza, Angelo Colla, p 346

6. French RK, Cunningham A (1998) Before science: the invention of the friars' natural philosophy, Scolar Press, London

7. Grmek MD, Bernabeo R (1996) La macchina del corpo. In: Storia del pensiero medico occidentale, vol II. Bari, Laterza, p 5

8. European Court of Justice, 18 oct 2011: (Directive 98/44/EC - Article 6(2)(c) - Legal protection of biotechnological inventions - Extraction of precursor cells from human embryonic stem cells Patentability - Exclusion of 'uses of human embryos for industrial or commercial purposes' - Concepts of 'human embryo' and 'use for industrial or commercial purposes' 